Канд. техн. наук Татарчук Т. В.

НУ «Запорізька політехніка», м. Запоріжжя

\title{
СТАТИСТИЧНЕ ДОСЛІДЖЕННЯ МІКРОСТРУКТУРИ ПОСТІЙНИХ МАГНІTІВ, СПЕЧЕНИХ ЗІ СПЛАВУ Nd-Fe-B,C-Cu,Ti
}

\begin{abstract}
Мета роботи. Статистичний аналіз мікроструктур готових постійних магнітів, щэо виготовляються на основі систем Fe-Nd-B при різних режимах термообробки.

Методи дослідження: металографічний, рентгеноспектральний, статистичний, магнітометричний.

Отримані результати. У роботі досліджується вплив зовнішнього тиску на структуру та властивості постійних магнітів складу $\mathrm{Nd}_{15,2} \mathrm{Fe}_{74,99} \mathrm{C}_{0,51} B_{6,6} \mathrm{Cu}_{1,57} \mathrm{Ti}_{1,38}$. Для виготовлення постійних магнітів 3 високою магнітною енергією використано продукти швидкого охолодження з рідкого стану. Для иього лусочки, щзо отримані методом ЗРС, пресували у прес-формі та спікали у вакуумі. Прес-форма та болти, щуо їх скріплюють, виготовлені зі сплавів, у яких різні коефічієнти лінійного розширення. Цей метод дає змогу досягти високого тиску $(H \approx 1$ ГПа) під час спікання. Спікання виконували у вакуумі під тиском $P=0,5 \ldots 12$ МПа та при mемпературах $1323 \mathrm{~K}$ ma $1013 \mathrm{~K}$.

Показано, щзо розміри частинок фази $\mathrm{NdCu}$ підпорядковується закону Гауса та у розподілі присутні два піки. Перший пік можна пояснити наявністю у вихідних плівках аморфної складової, у якій знаходяться зародки основної магнітної фази $\mathrm{Nd}_{2} \mathrm{Fe}_{14} \mathrm{~B}$ та парамагнітної фази $\mathrm{NdCu}$, а другий пік пояснюється тим, що у кристалічній області вже є зерна парамагнітної фази $\mathrm{NdCu}$ i при подальшому спіканні вони продовжують зростати. Також показано, щзо розмір часток фази $\mathrm{NdCu}$, які присутні у спеченому зразку, щчо отриманий при початковому тиску 12 МПа, зменшився до 0,03...0,5 мкм порівняно з середнім розміром 0,23...0,94 мкм для менших значень початкового тиску. При изьому коерцитивна сила компактів зросла на порядок від 160 кА/м до $1300 \kappa A / \mathrm{M}$
\end{abstract}

Наукова новизна. Встановлено, щз зниження температури спікання швидко охолоджених лусочок сплавів $\mathrm{Nd}{ }_{15,2} \mathrm{Fe}_{75,5-x} \mathrm{C}_{x} B_{6,6} \mathrm{Cu}_{1,57} \mathrm{Ti}_{1,38}$ в умовах високого тиску порядку 0,9 ГПа від технологічної $1323 \mathrm{~K}$ до температури $1013 \mathrm{~K}$ практично не впливає на швидкість зародження метастабільних фаз $\mathrm{NdCu}_{2} \mathrm{ma} \mathrm{Nd}_{2} \mathrm{Fe}_{14} \mathrm{~B}$ i в той же час знижує швидкість їх росту. Однак, иุе призводить до збільшення коерциттивної сили готових магнітів від $160 \kappa A /$ м до $1300 \kappa A / м$.

Практична цінність. Одержані в роботі результати мають важливе значення для подальшого розвитку фізичного матеріалознавства магнітожорстких матеріалів та сучасної техніки.

Ключові слова: спікання, «термічний» тиск, відпал, основна магнітожорстка фаза, фаза з обмеженою метастабільністю, коеричитивна сила, метод січних.

Вступ

Сучасне промислове виробництво прецизійної техніки, мікроелектроніки, літакобудування, ракетобудування ставить високі вимоги до матеріалів. Основними критеріями, які повинні характеризувати матеріали, $\epsilon$ висока якість, мала собівартість, мінімальна матеріалоємність при збереженні найкращих фізико-механічних властивостей виробів в робочих умовах.

В світовій та вітчизняній літературі, окрім пошуку методів комплексного легування та створення нових сполук, мало приділяється уваги розробці нових способів виготовлення постійних магнітів, а саме, використанню одного з термодинамічних параметрів тиску для управління процесами кристалізації та спікання постійних магнітів. Тому в даній роботі досліджено вплив зовнішнього тиску на мікроструктуру спечених компактів та виконано статистичний аналіз мікроструктур після термообробки магнітожорстких сплавів $\mathrm{Nd}-\mathrm{Fe}-\mathrm{B}$.

\section{Матеріали та методи дослідження}

В якості вихідних матеріалів для одержання спече-

(C) Татарчук T. В., 2020

DOI 10.15588/1607-6885-2020-1-5

34 них компактів використовували швидко загартовані стрічки складу $\mathrm{Nd}_{15,2} \mathrm{Fe}_{75,08} \mathrm{Cu}_{1,57} \mathrm{~B}_{6,5} \mathrm{C}_{0,42} \mathrm{Ti}_{1,38}$. Режими термообробки подано у табл. 1 .

\section{Результати та обговорення}

На рис. 1 представлено мікроструктури зразків, які було виристано для статистичної обробки. Згідно результатів хімічного аналізу білі включення являють собою неферомагнітну фазу, яка ізоструктурна фазі $\mathrm{NdCu}_{2}$. Для визначення розмірів включень використовували метод січних [3]. Для визначення концентрації мікрочастинок у об’ємі сплаву використовували наступну формулу:

$$
N=\frac{n}{D_{c e p}} \mathrm{MM}^{-3},
$$

де $N$ - число шаровидних частинок в одиниці об'єму, $D_{c e p}$ - діаметр шаровидних частинок, $n$ - середня кількість перерізів на одиницю площини. 
Таблиця 1 - Режими спікання та відпалу сплаву $\mathrm{Nd}_{15,2} \mathrm{Fe}_{75,08} \mathrm{C}_{0,42} \mathrm{~B}_{6,6} \mathrm{Cu}_{1,57} \mathrm{Ti}_{1,38}$

\begin{tabular}{|c|c|c|c|c|c|c|c|c|c|c|}
\hline \multirow{2}{*}{ 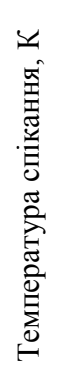 } & \multirow{2}{*}{ 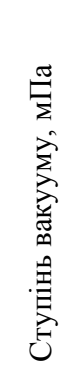 } & \multirow[b]{2}{*}{ 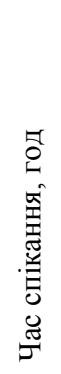 } & \multirow{2}{*}{ 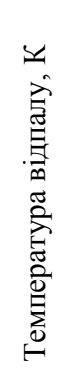 } & \multirow[b]{2}{*}{ 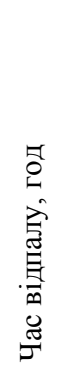 } & \multicolumn{3}{|c|}{ Початковий тиск, МПа } & \multirow{2}{*}{ 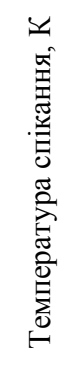 } & \multirow{2}{*}{ 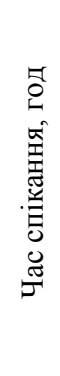 } & \multirow{2}{*}{ 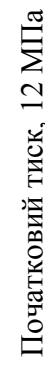 } \\
\hline & & & & & 0,5 & 3 & 9,5 & & & \\
\hline 1323 & 1,333 & 1 & 823 & 0,5 & + & + & + & 1013 & 1,5 & + \\
\hline
\end{tabular}
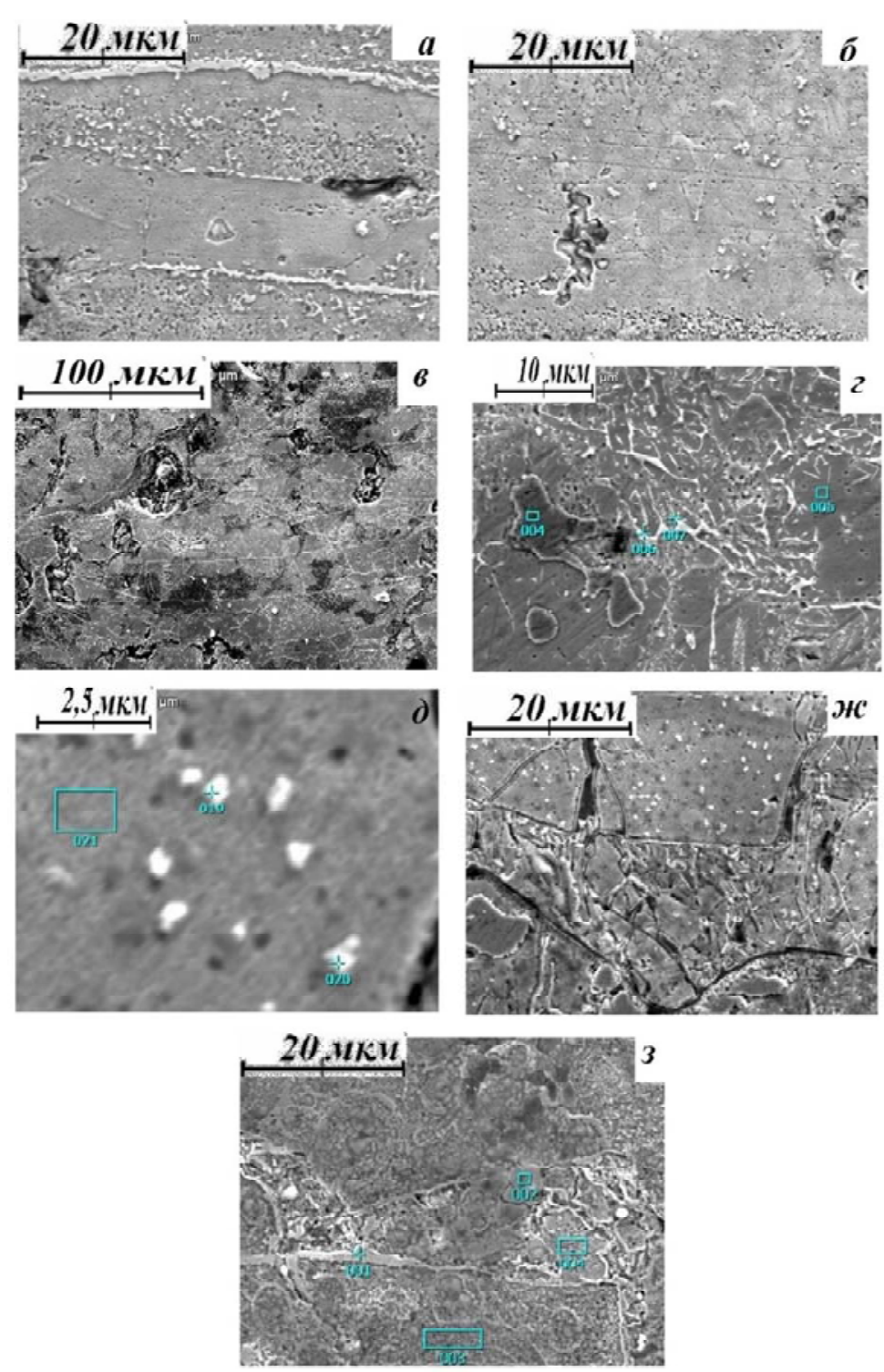

Рис. 1. Мікроструктури зразків складу $\mathrm{Nd}_{15,2} \mathrm{Fe}_{74,99} \mathrm{C}_{0,51} \mathrm{~B}_{6,6} \mathrm{Cu}_{1,57} \mathrm{Ti}_{1,38}$, що були отримані за допомогою електронного мікроскопа: $a, \sigma-9,5$ МПа;, , $2-3$ МПа; $\partial, \nsim-12$ МПа; 3 - 0,5 МПа $[1,2]$

Для визначення реальної кількості включень у об’ємі зразка врахували, що спечені компакти мали форму циліндра діаметром 5 мм та висотою 4 мм. У табл. 2 подано порівняня параметрів фрагментів фази $\mathrm{NdCu}_{2}$ для компактів сплаву $\mathrm{Nd}_{15,2} \mathrm{Fe}_{74,99} \mathrm{C}_{0,51} \mathrm{~B}_{6,6} \mathrm{Cu}_{1,57} \mathrm{Ti}_{1,38}$, що спечені в різних умовах. На рис. 2 представлено діаграму розподілу частинок фази $\mathrm{NdCu}_{2}$ за розмірами для компакту складу $\mathrm{Nd}_{15,2} \mathrm{Fe}_{74,99} \mathrm{C}_{0,51} \mathrm{~B}_{6,6} \mathrm{Cu}_{1,57} \mathrm{Ti}_{1,38}$. Також на 
рис. 2 подано мікроструктуру вихідної плівки даного складу $[1,2]$. Видно, що плівка має кристалічну та аморфну складові. У подальшому при спіканні з кристалічної складової продовжується ріст основної магнітної фази $\mathrm{Nd}_{2} \mathrm{Fe}_{14} \mathrm{~B}$ та парамагнітної фази $\mathrm{NdCu}_{2}$.

В роботі проведено статистичний аналіз із побудовою розподілу за розмірами частинок $\mathrm{NdCu}_{2}$ в спечених компактах. 3 рис. 2 видно, що розмір часток фази $\mathrm{NdCu}_{2}$, які присугні у спеченому зразку, що отриманий при початковому тиску 12 МПа, зменшився до 0,03 ...0,5 мкм порівняно з середнім розміром 0,23 ...0,94 мкм для попередніх умов спікання (див. рис. 1, табл. 1).

Якщо розподіл за розмірами зерен підпорядковується закону Гауса, то слід чекати, що у зразку присутні частинки фази $\mathrm{NdCu}_{2}$ (сферичної форми) значно меншого розміру (<0,05 мкм, рис. $1 \partial, ж)$. Наявність таких частинок має призвести до значного зростання коерцитивної сили. Як показано в роботі, імовірність існування часток фази $\mathrm{NdCu}_{2} 3$ розмірами меншими за 0,05 мкм надзвичайно висока, то можна з впевненістю сказати, що ефект пінінгу вносить основний вклад до механізму збільшення коерцитивної сили. Наявність двох піків на діаграмі можна пояснити будовою вихідних стрічок. У кристалічній області вже є зерна парамагнітної фази $\mathrm{NdCu}_{2}$ і при подальшому спіканні вони продовжують зростати. Цим пояснюється другий пік на діаграмі. Перший пік можна пояснити наявністю у вихідних плівках аморфної складової, у якій знаходяться зародки основної магнітної фази $\mathrm{Nd}_{2} \mathrm{Fe}_{14} \mathrm{~B}$ та парамагнітної фази $\mathrm{NdCu}_{2}$.

Згідно з розрахунками, загальна кількість зерен фази $\mathrm{NdCu}_{2}$, що припадають на 1 мм $^{3}$, складає:

$$
N_{3 a 2}=\sum N_{k} \text {. }
$$

Щоб перевірити цей результат, цю ж величину було розраховано за формулою С. А. Салтикова [14]:

$$
N=\frac{2}{\pi} \sum_{i=1}^{k}\left(\frac{1}{d_{i}} \cdot n_{i}\right) .
$$

Якщо враховувати, що в лусочках, що мали аморфну будову, зерен фази $\mathrm{NdCu}_{2}$ не було виявлено, то можна зробити висновок, що всі вони зародилися під час спікання, яке тривало час $t$. Аналізуючи графік, зображений на рис. 2, безпосередньо під час спікання утворилася лише частина зерен. Вважаючи, що за час $t$ зародилися зерна, які після завершення спікання мали діаметр $D \in(0 ; 500 \mathrm{Hм})$, можна приблизно оцінити швидкість зародкоутворення фази $\mathrm{NdCu}_{2}$ у компакті складу $\mathrm{Nd}_{15,2} \mathrm{Fe}_{74,991} \mathrm{~B}_{6,6} \mathrm{C}_{0,51} \mathrm{Cu}_{1,57} \mathrm{Ti}_{1,38}$ під час спікання. Тоді середня швидкість зародкоутворення:

$$
I_{c e p}=\frac{N_{c e p}}{t}
$$

\begin{tabular}{|c|c|c|c|c|c|c|c|c|}
\hline \multirow{2}{*}{$\begin{array}{c}\text { Проміжок, } \\
\text { нм }\end{array}$} & \multicolumn{2}{|c|}{ 0,5 МПа } & \multicolumn{2}{|c|}{3 МПа } & \multicolumn{2}{|c|}{ 9,5 МПа } & \multicolumn{2}{|c|}{$12 \mathrm{MПа}$} \\
\hline & Dcep, нм & $N, \mathrm{mM}^{-3}$ & Dcep, нм & $N, \mathrm{MM}^{-3}$ & Dcep, нм & $N, \mathrm{MM}^{-3}$ & Dcep, нм & $N, \mathrm{MM}^{-3}$ \\
\hline $0-50$ & - & - & - & - & - & - & 33,505 & 26074317 \\
\hline $50-150$ & 147,06 & 4113881 & 76,923 & 19290862 & 116,279 & 8563756 & 127,091 & 5311706 \\
\hline $150-250$ & - & - & 185,375 & 32553318 & 232,56 & 9308351 & 176,923 & 2917823 \\
\hline $250-350$ & 294,12 & 2430930 & 307,69 & 9002461 & 348,84 & 3475118 & 262,779 & 5742392 \\
\hline $350-450$ & 441,18 & 2617924 & 384,62 & 5144163 & - & - & 393,424 & 3028031 \\
\hline $450-550$ & - & - & 489,511 & 4446075 & 465,12 & 8377515 & 526,32 & 3017936 \\
\hline $550-650$ & 588,24 & 1869946 & 615,38 & 321517 & 581,4 & 1861670 & - & - \\
\hline $650-750$ & 735,29 & 747989 & 692,31 & 428684 & 697,67 & 2420206 & 657,89 & 1086473 \\
\hline $750-850$ & - & - & 769,23 & 128606 & 813,95 & 478721 & 789,47 & 352097 \\
\hline $850-950$ & 882,35 & 498658 & - & - & 930,23 & 837761 & - & - \\
\hline $950-1050$ & 1029,41 & 213710 & 943,4 & 2621566 & 1046,51 & 206854 & - & - \\
\hline $1050-1150$ & - & - & - & - & - & - & 1052,63 & 75449 \\
\hline $1150-1250$ & 1176,47 & 327243 & - & - & 1162,79 & 297870 & - & - \\
\hline $1250-1350$ & 1323,53 & 41555 & - & - & 1279,07 & 169244 & - & - \\
\hline $1350-1450$ & - & - & 1415,09 & 1398178 & 1395,35 & 31028 & - & - \\
\hline $1450-1550$ & 1470,59 & 112198 & - & - & - & - & - & - \\
\hline $1550-2000$ & 1764,71 & 31166 & 1886,79 & 524316 & - & - & - & - \\
\hline $2000-3000$ & 2058,82 & 26715 & 2539,913 & 506339 & - & - & - & - \\
\hline $3000-4000$ & - & - & 3771,233 & 5272654 & - & - & - & - \\
\hline
\end{tabular}

Таблиця 2 - Результат статистичної обробки для спечених при різному початковому тиску компактах складу $\mathrm{Nd}_{15,2} \mathrm{Fe}_{74,99} \mathrm{C}_{0,51} \mathrm{~B}_{6,6} \mathrm{Cu}_{1,57} \mathrm{Ti}_{1,38}$ 


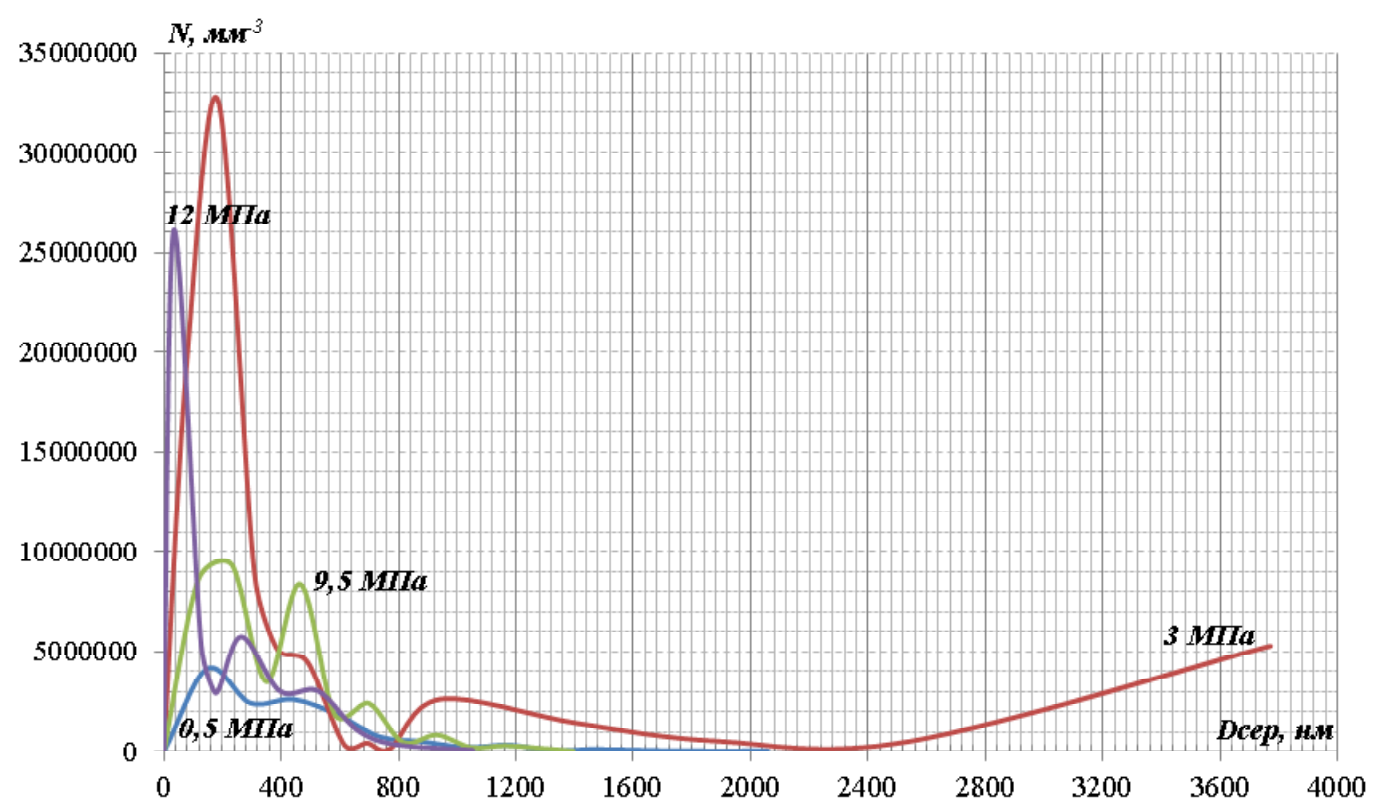

Рис. 2. Діаграма розподілу частинок фази $\mathrm{NdCu}_{2}$ за розмірами для компакту складу $\mathrm{Nd}_{15,2} \mathrm{Fe}_{74,99} \mathrm{C}_{0,51} \mathrm{~B}_{6,6} \mathrm{Cu}_{1,57} \mathrm{Ti}_{1,38}$

Якщо вважати, що швидкість зародкоутворення постійна величина, то в середньому зерно зростало у проміжку часу $t / 2$, де $t$ - час спікання. Тому для приблизної оцінки швидкості росту зерен фаз $\mathrm{NdCu}_{2}$, скористувалися наступною формулою:

$$
v_{c e p}=2 \frac{D_{c e p}}{t}
$$

Щоб підрахувати $D_{\text {сер }}$ було використано дані розподілу зерен фази $\mathrm{NdCu}_{2}$ за розмірами:

$$
D_{\text {cep }}=\frac{\sum\left(D_{k} N_{k}\right)}{N_{3 a z}},
$$

де $N_{k}$ - кількість зерен фази $\mathrm{NdCu}_{2}$ та діаметром $D_{k}$ в одиниці об'єму.

Результати розрахунків подано у табл. 3 .

Таблиця 3 - Порівняльна таблиця параметрів фрагментів фази $\mathrm{NdCu}_{2}$ для компактів сплаву

\begin{tabular}{|c|c|c|c|c|c|c|c|c|}
\hline Сплав & \multicolumn{3}{|c|}{ Умови спікання } & \multicolumn{5}{|c|}{ Параметри фрагментів фази $\mathrm{NdCu}_{2}$ у спеченому компакті } \\
\hline \multirow[t]{5}{*}{ 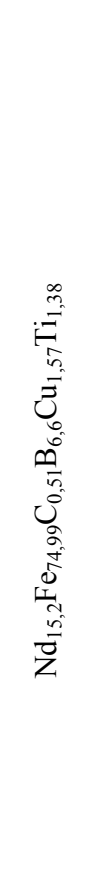 } & 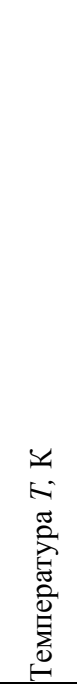 & 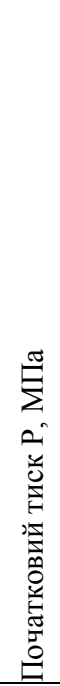 & 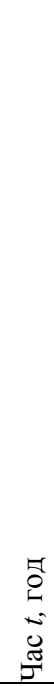 & 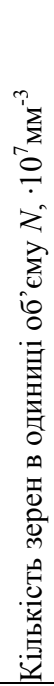 & 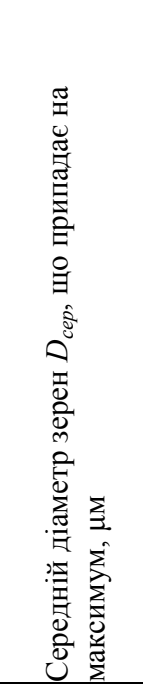 & 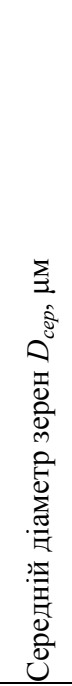 & 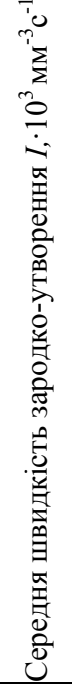 & 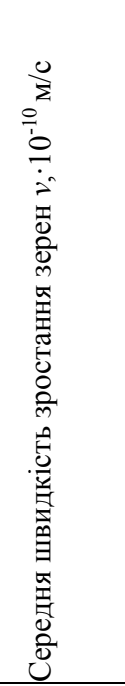 \\
\hline & \multirow{3}{*}{1323} & 0,5 & \multirow{3}{*}{0,5} & 1,3 & $015 / 0,94$ & 0,63 & 18,3 & 7 \\
\hline & & 3 & & 8,2 & $0,19 / 0,7$ & 0,67 & 45,6 & 7,44 \\
\hline & & 9,5 & & 5,2 & $0,23 / 0,47$ & 0,51 & 48,9 & 5,67 \\
\hline & 1013 & 12 & 1,5 & 4,7 & $0,03 / 0,26$ & 0,36 & 8,7 & 1,33 \\
\hline
\end{tabular}
$\mathrm{Nd}_{15,2} \mathrm{Fe}_{74,99} \mathrm{C}_{0,51} \mathrm{~B}_{6,6} \mathrm{Cu}_{1,57} \mathrm{Ti}_{1,38}$, що спечені в різних умовах 
Видно, що середній діаметр для включень майже однаковий (у рамках похибки), швидкість зародкоутворення падає у межах 2...5,6 разів, а швидкість зростання частинок - падає у межах 4,2 ..5,6 рази зі зниженням температури спікання. Саме цим можна пояснити різницю максимальної кількості частинок фази $\mathrm{NdCu}_{2}$ в об'ємі компакту та існування кількох піків, які зміщенні один відносно одного.

Спечені компакти досліджували на вібраційному магнітометрі для встановлення значень коерцитивної сили $\mathrm{H}_{\text {сі }}$ та залишкової індукції В зразка (рис. 4).

В умовах високого тиску виникають напруги, які прискорюють дифузійні процеси в зразку [4-6]. Таким чином, з одного боку здійснюється об'ємне зростання фаз $\mathrm{Nd}_{2} \mathrm{Fe}_{14} \mathrm{~B}$ i NdCu та при цьому стійкість їх буде стабільною, оскільки високий тиск зміщує точки фазової рівноваги в області високих температур відповідно до закону Клапейрона-Клаузіуса. Як видно з рис. 1, розмір фази $\mathrm{NdCu}_{2}$ при збільшенні первинного тиску від 0,5 МПа до 9,5 МПа, практично однаковий і становить у середньому 0,57 мкм.

Оскільки фаза $\mathrm{Nd}_{2} \mathrm{Fe}_{14} \mathrm{~B}$ в даних умовах не встигає сформуватися в окремі зерна, а розміри фази $\mathrm{NdCu}_{2}$ такі, що не перешкоджають руху границь доменів, то в цьому випадку значення коерцитивної сили зразка залишається практично постійним. Для того, щоб уникнути швидкого зростання фази $\mathrm{NdCu}_{2}$, збільшили первинний тиск і знизили температуру спікання до температури потрійної легкоплавкої евтектики (1013 К), а час спікання збільшили до 1,5 год. Ці умови практично не вплинули на швидкість зародження фаз $\mathrm{NdCu}_{2}$ та $\mathrm{Nd}_{2} \mathrm{Fe}_{14} \mathrm{~B}$ і в той же час знизили швидкість росту цих фаз. Як видно з рисунку 1 , розмір фази $\mathrm{NdCu}_{2}$ зменшився до 0,3 мкм, а в деяких випадках і до 0,03 мкм та при цьому коерцитивна сила компактів зросла на поря- док від 160 кА/м до 1300 кА/м. Поряд з цим в аморфній складовій плівок проходить кристалізація стабільних і метастабільних фаз в умовах високого тиску. Аморфна складова являє собою невпорядковану структуру 3 відсутністю далекого порядку і тому в даних умовах щільність недосконалостей прагне до максимуму, а також прискорюються процеси перенесення легувальних елементів, а саме, вуглецю, міді та титану, в зону скупчень недосконалостей (хмара Сузукі-Котрелла, ядра дислокації та ін.). Досягаючи критичних розмірів, скупчення недосконалостей, збагачені легувальними елементами, також стають перешкодою зміщення границь доменів.

\section{Висновки}

1. Статистичний аналіз мікроструктур компактів складу $\mathrm{Nd}_{15,2} \mathrm{Fe}_{74,99} \mathrm{C}_{0,51} \mathrm{~B}_{6,6} \mathrm{Cu}_{1,57} \mathrm{Ti}_{1,38}$ спечених при різних умовах, показав наявність двох піків на розподілі Гауса. Причому, збільшення початкового тиску сприяє зменшенню розмірів частинок фази $\mathrm{NdCu}_{2}(<0,05$ мкм). Тому можна вважати, що ефект пінінгу вносить основний вклад до механізму збільшення коерцитивної сили.

2. Спікання швидкоохолоджених лусочок $\mathrm{Nd}_{15,2} \mathrm{Fe}_{74,99} \mathrm{C}_{0,51} \mathrm{~B}_{6,6} \mathrm{Cu}_{1,57} \mathrm{Ti}_{1,38}$ в умовах зовнішнього тиску до 1 ГПа при температурі $T=1323$ К сприяє об'ємному зростанню фази $\mathrm{NdCu}_{2}$, але не призводить до іiі розпаду, що в свою чергу негативно впливає на величину коерцитивної сили та залишкової індукції компактів.

3. При зниженні температури спікання до 1013 К в умовах високого зовнішнього тиску, процес росту метастабільних фаз сповільнюється, що дозволяє отримати в компакті нанорозмірні утворення фази $\mathrm{NdCu}_{2}$, які перешкоджають руху границь доменів. Це підвищує значення коерцитивної сили на порядок $\left(H_{C}=\right.$ $=1350 \kappa \mathrm{A} / \mathrm{M})$.
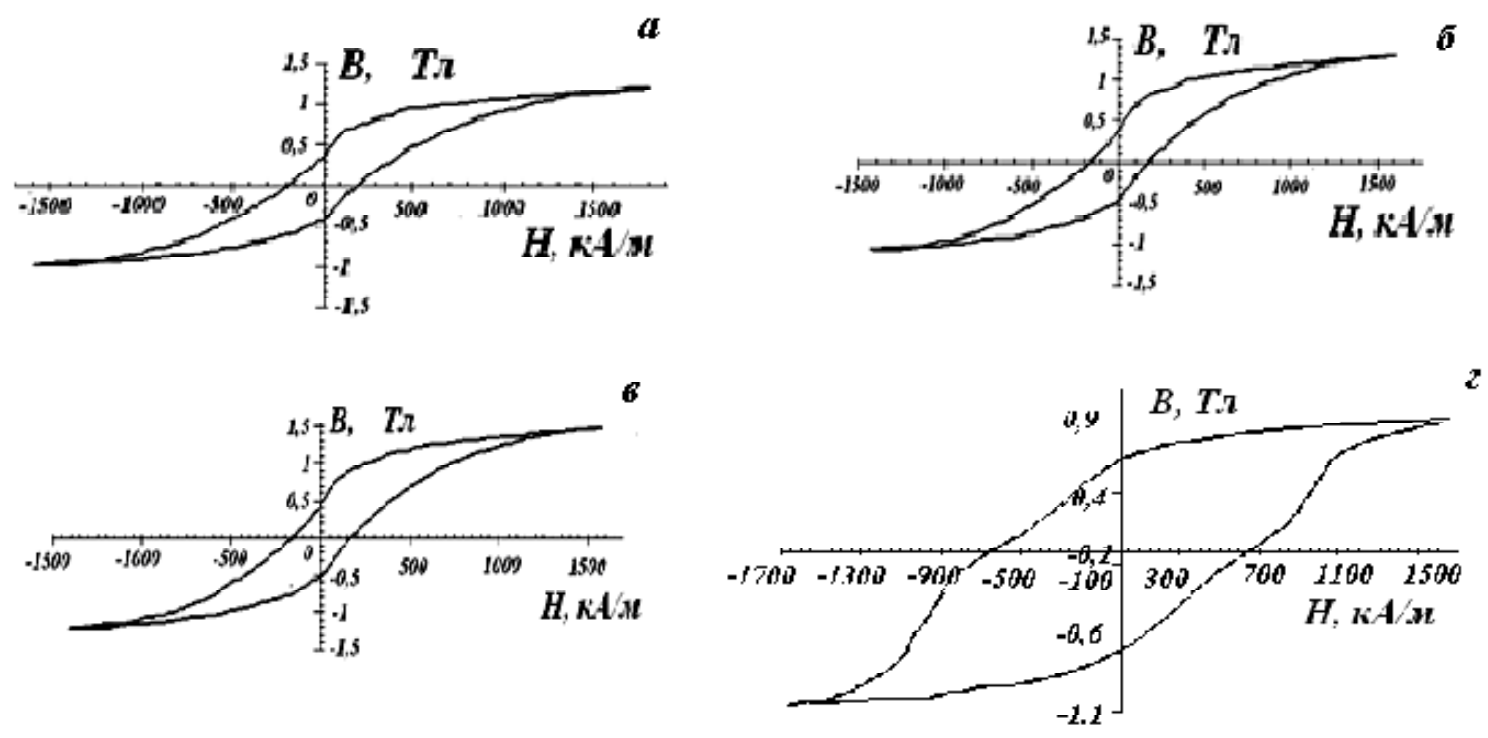

Рис. 4. Петлі гістерезісу компактів, які були спечені зі сплаву $\mathrm{Nd}_{15,2} \mathrm{Fe}_{74,99} \mathrm{C}_{0,51} \mathrm{~B}_{6,6} \mathrm{Cu}_{1,57} \mathrm{Ti}_{1,38}$ при різному початковому тиску: $a-0,5$ МПа; $\sigma-3$ МПа; $в$ - 9,5 МПа; $2-12$ МПа [4] 


\section{Список літератури}

1. Gulyaeva T. V. On the study of the influence of external pressure and carbon on structure and properties of compacts made on the basis of rapidly cooled alloys of Nd-Fe-(B,C)$\mathrm{Cu}-\mathrm{Ti}$ (Part 2) / T. V. Gulyaeva, G. P. Brekharya- Innovative materials and technologies in metallurgy and mechanical engineering, № 1. -2019 . - P. 20-30.

2. Gulyaeva T. V. On the study of the influence of external pressure and carbon on structure and properties of compacts made on the basis of rapidly cooled alloys of Nd-Fe-(B,C)$\mathrm{Cu}-\mathrm{Ti} / \mathrm{T} . \mathrm{V}$. Gulyaeva. - Innovative materials and technologies in metallurgy and mechanical engineering, № 1, 2018. - P. 33-40. DOI 10.15588/1607-6885-2018-1-5

3. Салтыков С. А. Стереометрическая металлография / С. А. Салтыков. - М. : Металлургия, 1976. - 271 с.
4. Брехаря Г. П. Свойства постоянных магнитов системы $\mathrm{Nd}-\mathrm{Fe}-\mathrm{B}$, легированной $\mathrm{Cu}, \mathrm{Ti}, \mathrm{C}$, полученных порошковым методом или спеканием пленок в условиях высокого давления / Г. П. Брехаря, Е. А. Харитонова, Т. В. Гуляева // Успехи физики металлов. - К. : ИМФ.T. 15. - 2014. - C. 35-53.

5. Шьюмон П. Дифузия в твердых телах / П. Шьюмон; [пер. с англ.]. - М. : Металлургия, 1966. - 195 с.

6. Дудоров А. Е. Уравнения динамики и кинетики дислокаций при высоких скоростях пластической деформации / А.Е. Дуров, А.Е. Майер // Вестник Челябинского государственного университета, Физика. - 2011. Вып. 12. - № 39 (254). - С. 48-56.

Одержано 30.12 .2020

Татарчук Т. В. Статистическое исследование микроструктуры постоянных магнитов, спеченных из сплава Nd-Fe-B, C-Cu, Ti

Цель работы. Статистический анализ микроструктур готовых постоянных магнитов, изготовленных на основе систем $\mathrm{Fe}-\mathrm{Nd}-\mathrm{B}$ при различных режимах термообработки.

Методы исследования: металлографический, рентгеноспектральный, статистический, магнитометрический.

Полученные результаты. В работе исследуется влияние внешнего давления на структуру и свойства постоянных магнитов состава $\mathrm{Nd}_{15,2} \mathrm{Fe}_{74,99} \mathrm{C}_{0,51} \mathrm{~B}_{6,6} \mathrm{Cu}_{1,57} \mathrm{Ti}_{1,38}$. Для изготовления постоянных магнитов с высокой магнитной энергией использованы продукты быстрого охлаждения из жидкого состояния. Для этого чешуйки, полученные методом ЗЖС, прессовали в пресс-форме и спекали в вакууме. Пресс-форма и болты, которые скрепляют, изготовлены из сплавов, у которых коэффициенты линейного расширения различны. Этот метод позволяет достичь высокого давления (Н 1 ГПа) при спекании. Спекания выполняли в вакууме под давлением $P=0,5$.. 12 МПа и при температуре $1323 \mathrm{~K} \mathrm{и} 1013 \mathrm{~K}$. Показано, что размеры частиц фазы $\mathrm{NdCu}$, подчиняются закону Гаусса и в распределении присутствуют два пика. Первый пик можно объяснить наличием в исходных пленках аморфной составляющей, в которой находятся зародыши основной магнитной фазы $\mathrm{Nd}_{2} \mathrm{Fe}_{14} \mathrm{~B}$ и парамагнитной фазы $\mathrm{NdCu}$, а второй пик объясняется тем, что в кристаллической области уже есть зерна парамагнитной фазы $\mathrm{NdCu}$ и при дальнейшем спекании они продолжают расти. Также показано, что размер частиц фазы $\mathrm{NdCu}$, которые присутствуют в спеченном образие, полученный при начальном давлении 12 МПа, уменьшился до 0,03 ... 0,5 мкм по сравнению со средним размером 0,23 ... 0,94 мкм для меньших значений начального давления. При этом коэричтивная сила компактов выросла на порядок $160 \kappa A /$ м до $1300 \kappa A /$ м.

Научная новизна. Установлено, что снижение температуры спекания быстро охлажденных чешуек сплавов $\mathrm{Nd}_{15,2} \mathrm{Fe}_{74,99} \mathrm{C}_{0,51} B_{6,6} \mathrm{Cu}_{1,57} \mathrm{Ti}_{1,38}$ в условиях высокого давления порядка 0,9 ГПа от технологической $1323 \mathrm{~K}$ до температуры $1013 \mathrm{~K}$ практически не влияет на скорость зарождения мета стабильных фаз $\mathrm{NdCu}_{2} u \mathrm{Nd}_{2} \mathrm{Fe}_{14} \mathrm{~B}$ и в то же время снижает скорость их роста. Однако, это приводит к увеличению коэричтивной силы готовых магнитов $160 \kappa A$ / м до $1300 \kappa A /$ м.

Практическая ценность. Полученные в работе результаты имеют важное значение для дальнейшего развития физического материаловедения магнитожестких материалов и современной техники.

Ключевые слова: спекание, «термическое» давление, отжиг, основная магнитожесткая фаза, фаза с ограниченной метастабильнистю, коэричитивная сила, метод секущиих.

\section{Tatarchuk T. Statistical study of the microstructure of permanent magnets made from Nd-Fe-B,C-Cu,Ti alloy}

Purpose of work. Statistical analysis of microstructures of ready-made permanent magnets, which are made on the basis of Fe-Nd-B systems at different heat treatment modes. Research methods: metallographic, X-ray spectral, statistical, magnetometric. 
Research methods: metallographic, X-ray spectral, statistical, magnetometric.

The results obtained. The influence of external pressure on the structure and properties of permanent magnets of composition $\mathrm{Nd}{ }_{15,2} \mathrm{Fe}_{74,99} \mathrm{C}_{0,51} B_{6,6} \mathrm{Cu}_{1,57} \mathrm{Ti}_{1,38}$ is investigated in the work. For the production of permanent magnets with high magnetic energy, fast cooling products from the liquid state are used. To do this, the scales obtained by the ZRS method were pressed in a mold and sintered in vacuum. The mold and the bolts that fasten them are made of alloys with different coefficients of linear expansion. This method allows to achieve high pressure $(H \approx 1$ GPa) during sintering. Sintering was performed in vacuum under a pressure of $P=0.5 \ldots 12 \mathrm{MPa}$ and at temperatures of $1323 \mathrm{~K}$ and $1013 \mathrm{~K}$. It is shown that the particle size of the $\mathrm{NdCu}_{2}$ phase obeys the Gaussian law and there are two peaks in the distribution. The first peak can be explained by the presence in the source films of an amorphous component, which contains the nuclei of the main magnetic phase $\mathrm{Nd}_{2} \mathrm{Fe}_{14} \mathrm{~B}$ and paramagnetic phase $\mathrm{NdCu}$, and the second peak is explained by the fact that in the crystal region there are grains of paramagnetic phase NdCu, and they continue to grow. It is also shown that the particle size of the $\mathrm{NdCu}$ phase present in the sintered sample obtained at an initial pressure of $12 \mathrm{MPa}$ decreased to $0.03 \ldots 0.5 \mathrm{~mm}$ compared to the average size of $0.23 \ldots 0.94 \mathrm{~mm}$ for smaller values of the initial pressure. The coercive force of compacts increased by an order of magnitude from $160 \mathrm{kA} / \mathrm{m}$ to $1300 \mathrm{kA} / \mathrm{m}$

Scientific novelty. It is established that the decrease in the sintering temperature of rapidly cooled scales of $\mathrm{Nd}_{15,2} \mathrm{Fe}_{74,99} \mathrm{C}_{0,51} \mathrm{~B}_{6,6} \mathrm{Cu}_{1,57} \mathrm{Ti}_{1,38}$ alloys under conditions of high pressure of the order of $0.9 \mathrm{GPa}$ from technological $1323 \mathrm{~K}$ to $1013 \mathrm{~K}$ temperature practically does not affect the rate of metal stable phases of $\mathrm{NdCu}$ and $\mathrm{Nd}_{2} \mathrm{Fe}, 4 \mathrm{~B}$ and at the same time reduces their growth rate. However, this leads to an increase in the coercive force of the finished magnets from $160 \mathrm{kA} / \mathrm{m}$ to $1300 \mathrm{kA} / \mathrm{m}$.

Practical value. The results obtained in this work are important for the further development of physical materials science of magnetohard materials and modern technology.

Key words: sintering, "thermal" pressure, annealing, main magnetohard phase, phase with limited metastability, coercive force, January method. 